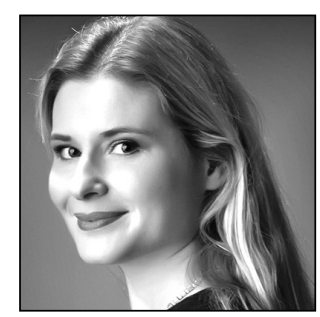

Goda Ambrasaite

Dr., Associate Professor Mykolas Romeris University, Vilnius Judge, Vilnius Regional Court

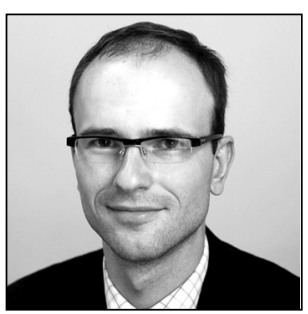

Rimvydas Norkus

Dr., Professor

Mykolas Romeris University, Vilnius

Judge, Supreme Court of Lithuania

\title{
Legal Aspects of \\ Insolvency of Natural Persons in the Baltic States
}

\section{Introduction}

After several years of intense discussions, the Law on Personal Bankruptcy of the Republic of Lithuania (LPB) came into force, on 1st March 2013. Lithuania was the last of the Baltic States to introduce a legal mechanism to deal with insolvency of a natural person to its legal system. In Estonia, provisions for proceedings for release of a debtor who is a natural persons from obligations took effect in 2004 (via Chapter 11 of the Bankruptcy Act), while in Latvia they were introduced in 2008 and substantially amended in 2010, with a view to facilitating and increasing the availability of bankruptcy proceedings.

The LPB is often criticised as being too laconic and leaving too many questions to be resolved by judicial practice, which has only begun its evolution. The purpose of this article, therefore, is to analyse the main features of the model for bankruptcy of a natural person as chosen by the Lithuanian legislator, in comparison with the legal regulation of the other states in its region-Latvia and Estonia-with particular emphasis on the principle of good faith and the need to balance the interests of the debtor and creditors. The authors attempt to assess whether initial judicial practice corresponds to the intents of the legislator and propose some solutions for more effective functioning of the legal institution of personal bankruptcy.

\section{Objectives in the establishment of a legal basis for bankruptcy of a natural person, adoption of the Law on Personal Bankruptcy of the Republic of Lithuania, and first experiences in its application}

The modern doctrine of a 'fresh start' reflects the difference between the previous paradigm, of punishment for an insolvent person, and the recent focus on economic activeness and efficiency ${ }^{*}$. By legalising the bankruptcy of an individual, two, at first glance contradictory, aims are pursued: to protect the interest of creditors and to grant a fresh financial start to the debtor by releasing him from some debts. In the opinion

P. Astromskis et al. Fizinio asmens bankroto problema: teisiniai aspektai ['The problem of bankruptcy of a natural person: Legal aspects']. - Jurisprudencija 121 (2010)/3, p. 214 (in Lithuanian). 
of some legal scholars, legalisation of bankruptcy of a natural person can be seen as legalisation of limited liability, since the purposes of this legal construction are the same as the purposes of the limited liability of companies ${ }^{{ }^{*}}$. This 'limited liability rule' is found to be very practicable both economically and socially as dividing the risks between the debtor and creditors and as granting the unfortunate debtor an opportunity to return to normal economic life. It is also connected with the need to equalise business conditions for a diverse range of businesses, since a situation wherein individuals involved in some forms of business activity are not granted the same tools as others to overcome financial difficulties may violate the constitutional principle of equality of persons ${ }^{*}$.

With regard to natural persons not involved in active economic activities (consumers), the main reasons for establishing a legal basis for bankruptcy are seen in the necessity of protecting human dignity, creating incentives to legalise future income, and avoiding imposing a burden caused by impoverishment on the state social system. Although opponents of the legalisation of bankruptcy of natural persons often stress the risk of a rise in negligent economic behaviour and other unwarranted risks, some surveys show that only $25-30 \%$ of cases of individuals' insolvency are caused by inadequate resource management or negligent behaviour, while the vast majority of them (as many as 70\%) result from increased financial obligations or decreased income (loss of one's job, sickness, etc.) ${ }^{*}$. Accordingly, the risk of negligent economic behaviour can be reduced through legal regulation enshrining the principles of fairness and prohibition of repeatability and should not serve as an insurmountable obstacle to creating a legal basis for personal bankruptcy proceedings.

When one considers the protection of creditors as one of the main aims of personal bankruptcy proceedings, the pari passu principle should be mentioned. The institution of personal bankruptcy is aimed at recovering debts from an insolvent individual in a civilised way by avoiding the principle of 'first come, first served'. It also helps to improve creditors' opportunities to recover debts by way of encouraging the debtor to legalise his future income.

Last but not least, since we are speaking about the necessity of establishing a legal basis for personal bankruptcy proceedings, the phenomenon of 'bankruptcy tourism'-'shopping' by debtors for favourable personal insolvency law-should be mentioned. As Lithuania was the only one of the Member States considered here where personal bankruptcy proceedings were not legalised, it was evident that introduction of such proceedings was necessary if Lithuania was to avoid citizens moving their centre of main interests (COMI) to other member states of the European Union in order to benefit from a legal regime more favourable to their proprietary interests.

The first draft law on personal bankruptcy in Lithuania was prepared already in October 2008 and was followed by intense discussion questioning both the necessity of legalisation of the bankruptcy of natural persons as such and its timeliness. After a time of unreasonably high prices for immovable property, before the economic crisis, along with high amounts of housing credit, legalisation of personal bankruptcy was, as could be expected, opposed mainly by commercial banks, who have levelled criticism especially at the provision whereby the law would be applied irrespectively of the time of the arising of debts-they argued that there was a violation of the lex retro non agit principle. It was asserted also that legalisation of personal bankruptcy would distort rational economic behaviour and lead to abuse, irresponsible borrowing, and an increase in the costs of obtaining credit. The draft law was not adopted by the legislator (the Seimas) at that time and was returned to the initiators for improvement ${ }^{*}$. The final draft Law on Personal Bankruptcy was submitted to the Seimas in March 2011, was adopted on 10 May 2012, and came into force on the 1st of March 2013.

2 E. Gruodytè, J. Kiršienè. Application of 'Fresh start' doctrine for individual debtors in Lithuania: EU and US perspective. Inžinerine Ekonomika-Engineering Economics 21 (2010)/3.

3 Nacionalinė verslo administratorių asociacija (National Association of Business Administrators). Taikomasis mokslinis tyrimas „Optimalaus individualia veikla užsiimančių fizinių asmenų, ūkininkų, kitų fizinių asmenų nemokumo problemų sprendimo modelio nustatymas" ["Applied scientific research "Establishment of the optimal model for solving insolvency problems of individual merchants, farmers, and other natural persons"'], p. 3. Available at http://www.ukmin.lt/web/ lt/verslo_aplinka/smulkaus-ir-vidutinio-verslo-politika/analizes_tyrimai_studijos_smulkus_verslas (31.3.2014) (in Lithuanian)

4 P. Astromskis et al. (see Note 1), p. 223.

5 Conclusions of the Committee of Economics of the Seimas on the Draft Law on Personal Bankruptcy, XIP-45o. Available at http://www3.lrs.lt/pls/inter3/dokpaieska.showdoc_l?p_id=361268 (1.4.2014) (in Lithuanian). 
Despite the criticism received, it was decided that the LPB should be applied to natural persons irrespective of the time of their liabilities arising. This decision was based on the idea that the new legal regulation does not worsen the legal position of creditors and that, on the contrary, a situation in which natural persons are unable to go bankrupt leads to inequality between individual creditors and, in addition, discourages the debtor from legalising his income, which circumstances result, in turn, reduces the real opportunities for creditors to satisfy their claims. ${ }^{* 6}$ It should be noted that such a solution was, in principle, found legitimate by the European Court of Human Rights (ECHR), who stated that in remedial social legislation and particularly in the field of debt adjustment, the opportunity must be open for the legislature to take measures affecting the further execution of previously concluded contracts in order to achieve the aim of the policy adopted" ${ }^{*}$.

In the first 10 months of validity of the LPB, about 350 applications to initiate personal bankruptcy proceedings were submitted to the courts. As of the time of this writing, the vast majority of bankruptcy applications in Lithuania have been presented by consumers unable to repay housing or consumer credit. Debts resulting from guarantee agreements are also common grounds for application. ${ }^{*}$ Personal bankruptcy debt amounts to, on average, 570,000 LTL (equivalent to 165,000 EUR) ${ }^{*}$. In mid-January 2014, personal bankruptcy proceedings had been started in cases of only 112 individuals and a payment plan approved for nine of them ${ }^{*}$. About a third of the applications were rejected at the initial stage of proceedings on account of non-compliance with procedural requirements. Initiation of personal bankruptcy proceedings was refused in 20 further cases predominantly on account of violation of the principle of good faith and inability of the debtor to satisfy the claims of the creditors at least partially.

\section{Models for a legal regime for bankruptcy of a natural person}

There are two traditionally recognised models for bankruptcy of a natural person: the Anglo-American model, or 'fresh start', and the continental European model, referred to as the 'earned fresh start'. The former envisages automatic discharge of the debtor's obligations upon liquidation of the assets of the debtor and is traditionally described as more favourable for the debtor. The latter, in contrast, emphasises the need to maximise returns to creditors; therefore, bankruptcy and cancellation of debt is possible only in cases of honest debtors who have complied with the payment plan and at least partially repaid the debts. In the context of continental Europe, a further three main models can be distinguished. The first of these, common to the Nordic countries, puts the main emphasis on the good faith of the debtor. Meanwhile, the German-Austrian model emphasises the payment plan and its implementation. Finally, the French model underscores preventive measures and envisages quite harsh conditions for the release from debt ${ }^{*}$. As will be evidenced further, the LPB is rightly said to be a reflection of the first two models (the Nordic and German) ${ }^{*}{ }^{12}$, and this seems to be true also for the other two Baltic States. However, it is important to point out that Lithuanian law does not provide for a separate procedure of bankruptcy (i.e., sale of the debtor's property and distribution of the proceeds to his creditors) and restructuring of natural persons' obligations,

6 Explanatory memorandum on the Draft Law on Personal Bankruptcy. Available at http://www3.lrs.lt/pls/inter3/dokpaieska. showdoc_l?p_id=395281 (1.4.2014) (in Lithuanian).

Judgement of the European Court of Human Rights, case of Bäck v. Finland, 20 July 2004.

8 I teismus plūstelejjo bankrutuoti siekiantys žmonès ['Courts are swamped by people who seek personal bankruptcy']. Available at http://www.delfi.lt/verslas/verslas/i-teismus-plustelejo-bankrutuoti-siekiantys-zmones.d?id=61997579 (31.3.2014) (in Lithuanian); Bankrutavo pirmasis fizinis asmuo Vilniaus mieste ['The first natural person went bankrupt in the city of Vilnius']. Available at http://www.alfa.lt/straipsnis/15147325/Bankrutavo.pirmasis.fizinis.asmuo.Vilniaus. mieste=2013-07-30_13-55/\#.Ut436aD8KM8 (31.3.2014) (in Lithuanian).

9 Suskaičiavo, kokių skolų prispausti bankrutuoja gyventojai ['It was calculated what amounts of debt compel people to go bankrupt']. Available at http://www.delfi.lt/verslas/verslas/suskaiciavo-kokiu-skolu-prispausti-bankrutuoja-gyventojai.d?id=63795122 (22.3.2014) (in Lithuanian).

10 Data on personal bankruptcy proceedings, presented by the Department of Enterprise Bankruptcy Management under the Lithuanian Ministry of Economy. Available at http://www.bankrotodep.lt/Doc/FABIS_G.pdf (21.1.2014) (in Lithuanian).

$11 \quad$ P. Astromskis et al. (see Note 1), p. 224.

12 E. Tamošiūnienė et al. Bankruptcy of natural persons in Lithuania: Issues and solutions. - European Scientific Journal 9 (2013)/22 (August), p. 78. 
as has been done in Estonia by introduction of the Debt Restructuring and Debt Protection Act. Personal bankruptcy proceedings in Lithuania are, in principle, debt restructuring proceedings closely resembling what is seen in restructuring of legal persons. The LPB puts the primary emphasis on restoration of the solvency of a natural person following the payment plan approved by the court. This payment plan functions by way of extending the term for fulfilment of obligations, the debtor performing the obligations in instalments, or reducing existing obligations through a total or partial liquidation of the debtor's assets.

In keeping with the chosen concept of personal bankruptcy as restructuring of debts, bankruptcy of a natural person in Lithuania is voluntary-creditors do not have the right to initiate bankruptcy proceedings for a natural person. In Latvia too, application to begin insolvency proceedings for a natural person may be submitted only by the debtor ${ }^{*}{ }^{13}$. These are not the same proceedings applicable for individual merchants (sole proprietors), who can be dealt with under the rules for insolvency of legal persons. In Estonia, bankruptcy proceedings can be initiated by either-the debtor or creditors-while a debt restructuring petition may be filed only by the debtor himself. These differences might be explained by the difference between debt restructuring and bankruptcy proceedings. With bankruptcy understood as sale of the debtor's assets and distribution of the proceeds among the creditors, the relevant interest of creditors in initiating proceedings of this type is evident. In contrast to the concept of bankruptcy, debt restructuring proceedings are applied mostly to serve the purpose of protecting the debtor from creditors' claims; hence, creditors normally have no personal interest in initiating restructuring proceedings. Since, at its core, the LPB deals with the restructuring of a natural person's debts (no matter the term 'bankruptcy' in its title), the voluntary nature of these proceedings appears to be the correct choice of path by the Lithuanian legislator.

\section{Insolvency of the debtor}

A necessary precondition for initiation of bankruptcy proceedings is insolvency of the debtor, which is defined in terms of criteria linked with overdue payments of debt, inability of the debtor to meet commitments, and the amount of the debt. According to Article 2 of the LPB, insolvency means inability of a natural person to perform his commitments when the past-due debts amount to at least 25 times the minimum monthly wage ${ }^{* 14}$, which amounts at present to 25,000 LTL (approx. 7,240 EUR). In the determination of insolvency, the creditors' claims that may not be written off are not taken into account. Those include claims for damages in relation to bodily injury or death, child-support payments, and claims arising from obligation to pay penalties to the state imposed for administrative or criminal offences. Quite similar conditions for the initiation of personal bankruptcy proceedings exist in Latvia, where insolvency proceedings for a natural person may begin if the person concerned does not have the possibility of settling debt obligations whose term of execution has run its course, where the debt obligations exceed 7,114 EUR in total. For the sake of comparison, it could be noted that the minimum monthly wage in Latvia in 2014 is 320 EUR; the financial threshold nearly matches that of Lithuania when considered in terms of the minimum monthly wages.

Imminent insolvency in Lithuania is not a basis for declaration of personal bankruptcy. This can be seen as a shortcoming of the national law, because a possibility of declaring personal bankruptcy if future insolvency is a matter of fact could prevent aggravating the financial situation of the debtor while at the same serving as protection of interests of both the debtor and the creditors. The possibility of initiation of personal bankruptcy proceedings in cases of reasonable expectation of future insolvency exists both in Estonia, where a court is entitled to declare someone bankrupt if insolvency is likely to occur and a bankruptcy petition is filed by the debtor ${ }^{* 15}$, and in Latvia, where insolvency proceedings for a natural person may be started if, in connection with provable circumstances, it will not be possible for that person to settle debt

13 According to the Latvian Insolvency Law, the person referred to in Article 29(a) of Council Regulation 1346/2000 (the liquidator appointed in the main insolvency proceedings) is also entitled to submit an application for the opening of proceedings for insolvency of a natural person. Nevertheless, such an indication in national legislation can be regarded as superfluous since the right of the liquidator to initiate secondary insolvency proceedings stems from Regulation 1346/2000 itself and does not require any implementation measures in national law.

14 The minimum monthly wage is approved by the Government of the Republic of Lithuania and at present amounts to 1,00o LTL per month

15 Article 31 of the Bankruptcy Act of Estonia, paragraph 3. 
obligations whose term of execution ends within the next year and the debt obligations exceed 14,228 EUR in total ${ }^{*} 16$. Yet it seems that the judicial practice of Lithuanian courts has gone even further in limiting the concept of insolvency, by stating that bankruptcy cannot be declared even from a state of formal insolvency unless it is established that the solvency of the debtor cannot be restored within reasonable time without the debtor going bankrupt:

The appellate court agrees with the conclusion of the court of first instance that, even if the overdue debts of the claimant exceed his or her property but the income of the debtor is sufficiently high, the meaning is that the debtor is able to repay debts [...]. A bona fide natural person is insolvent only when his or her financial situation is critical and he or she is absolutely unable to repay debts. ${ }^{* 17}$

Another court echoed this in its practice:

The applicant has a job, his monthly salary amounts to 1,600 LTL [and] he is of high non-university education. There is no evidence that in the last three years the applicant was aiming to reduce his obligations or extend the terms of payment by active means, such as via negotiations with creditors. [...]. In addition, the court takes into account the request of the debtor to establish the amount necessary to satisfy his needs of 1,300 LTL and explanation that he goes to work by taxi regardless of the fact that his workplace is just 4-5 kilometres away from his living place, along with the fact that the last credit was taken out to pay an attorney though the applicant could apply for the state's guaranteed legal aid [...]. The court decides that the applicant has a possibility of restoring his solvency without going bankrupt. ${ }^{*} 18$

Without disputing the fact that the behaviour of the debtor is fundamental in the decision on whether to initiate bankruptcy proceedings or not, one could raise doubts as to whether the considerations mentioned should be related to the formal concept of insolvency instead of being dealt with under the principle of good faith. Recent judicial practice, which draws no clear boundary between those two concepts, may be found to exclude personal bankruptcy without partial discharge from obligations-for example, with mere extension of the time limits for settling creditors' claims. In application of the judicial explanations cited, if the debtor is unable to perform his obligations but will be able to repay the debts within a five-year term, he would be recognised by the courts as solvent, which is hardly in line with the relevant legal regulation, since Lithuanian law does not provide for different courses of procedure in cases of bankruptcy vs. restructuring of natural persons' debts; the emphasis is on the restoration of the natural person's solvency through application of the provisions of the LPB. It should be mentioned that the Supreme Court of Lithuania has not yet had an opportunity to give its interpretation of the relevant provisions.

\section{The principle of good faith}

According to Article 1 of the LPB, the purpose of said law is to create conditions for restoration of the solvency of a natural person acting in good faith. Good faith of the debtor, as a core value and principle for personal bankruptcy proceedings in all of the Baltic States, is probably most clearly defined by Article 6 of the Latvian Insolvency Law, which states that 'a debtor may not use the proceedings in order to make a living unfairly', and, referring to the wording of one of the recent court rulings in Lithuania, that 'living not in accordance with one's income is not a proper basis for bankruptcy proceedings'. ${ }^{* 19}$ Within the framework of personal bankruptcy proceedings, good faith of the debtor should be explained as a situation wherein the insolvency has not been caused by malicious or grossly negligent actions on the part of the debtor. Following the provisions of the LPB, as well as the relevant provisions of the corresponding Estonian and Latvian legal acts, one could distinguish between two distinct aspects of the principle of good faith: acting in good faith before the filing of the bankruptcy petition (this aspect has to do primarily with the reasons for insolvency, such as the person not having become insolvent on account of dishonest transactions or addictions) and acting in good faith during the bankruptcy proceedings (this entails honesty in fulfilling

\footnotetext{
Article 129 of the Insolvency Law of Latvia, paragraph 1, item 2.

Ruling of Vilnius Regional Court on case $2 \mathrm{~S}-1628-345 / 2013$.

Ruling of Marijampolè District Court on case 2FB-3828-896/2013.

Ruling of Vilnius Region District Court on case 2FB-3418-723/2013.
} 
the relevant obligations arising from the personal bankruptcy laws after commencement of the bankruptcy proceedings). A bad-faith debtor cannot seek 'writing off' of his debts with respect to creditors who acted in good faith, as that would mean a violation of the principle of justice, unjustified interference with the proprietary interests of creditors, and distortion of the balance of the various interests in favour of the party in bad faith. ${ }^{{ }^{2} 0}$

Although some aspects of the principle of good faith are clearly defined by the law, it still leaves quite wide margins for judicial interpretation. The first question, which can arise immediately, is this: what kind of actions by the debtor causing insolvency should be assessed by the court as fraudulent or dishonest? Is there a margin for the court to qualify a certain behaviour of the debtor as 'dishonest' even if certain aspects of his behaviour are not expressly mentioned in the law (e.g., insufficient activeness in seeking employment or living in a manner not in accordance with his income)? Secondly, who bears the burden of proof? Is it an obligation of the debtor to prove that he was acting in good faith or, in line with the general rule in civil law, should good faith of the debtor be presumed? The question could also be raised of whether bad faith can be established only upon application of creditors or it is also for the court, acting for the protection of the public interest, to examine ex officio circumstances of the debtor's behaviour. Last but not least, is the condition of good faith of a procedural nature-i.e., can it serve as a basis on which the court can accept a bankruptcy petition or refuse acceptance thereof?-or is this condition of a substantive nature, one whose existence could be proved only after hearing of the case on its merits?

The answer to the last question could be found by following a systematic analysis of the LPB. Since the LPB directly lists bad faith of the debtor as one of the conditions for which the court should refuse the initiation of bankruptcy proceedings, it can be established only after hearing of the question on the merits, not in the initial stage of civil proceedings, and it may not serve as a basis for refusal to accept a bankruptcy petition. This is rightly noted by Lithuanian courts when hearing appeals on rulings of refusal to accept a petition for bankruptcy. ${ }^{* 21}$

When analysing the judicial practice of Lithuanian courts, one could note that the courts explain good faith of the debtor as being in line with a general obligation to act reasonably, with proper care and respect for existing obligations, and that they qualify certain behaviour of the debtor as dishonest even if such behaviour is not expressly mentioned in the LPB:

When taking out consumer credits, a person must evaluate his or her abilities to repay them. In this particular case, when one takes into account the income of the applicant and the amounts of credit taken out, it is evident that the applicant himself has caused his insolvency [...]. There is no evidence that taking out new consumer credit was necessary or unavoidable. The actions of the claimant-aggravation of his financial situation by taking out new credit and failure to repay existing debts-constitute a sufficient basis for deciding that the applicant was dishonest. ${ }^{{ }_{22}}$

Another illustrative example from case law is this:

The applicant, although unemployed at the moment, failed to comply even while still being employed with the requirements of the bailiff and had not presented any efforts to liquidate existing debts; on the contrary, the applicant had created additional obligations, such as that to pay fines for the refusal to comply with the requirements of the bailiff. ${ }^{*} 23$

Concealing essential information from creditors, using credit for a purpose other than that for which it was granted, ${ }^{* 24}$ buying expensive gifts for family members on lease without taking into account one's income and ability to fulfil obligations, ${ }^{{ } 25}$ granting an interest-free loan to one's company while at the same time failing to repay credit, ${ }^{{ }^{2} 6}$ and failing to seek employment ${ }^{{ }^{*} 27}$ are other examples of actions by a debtor

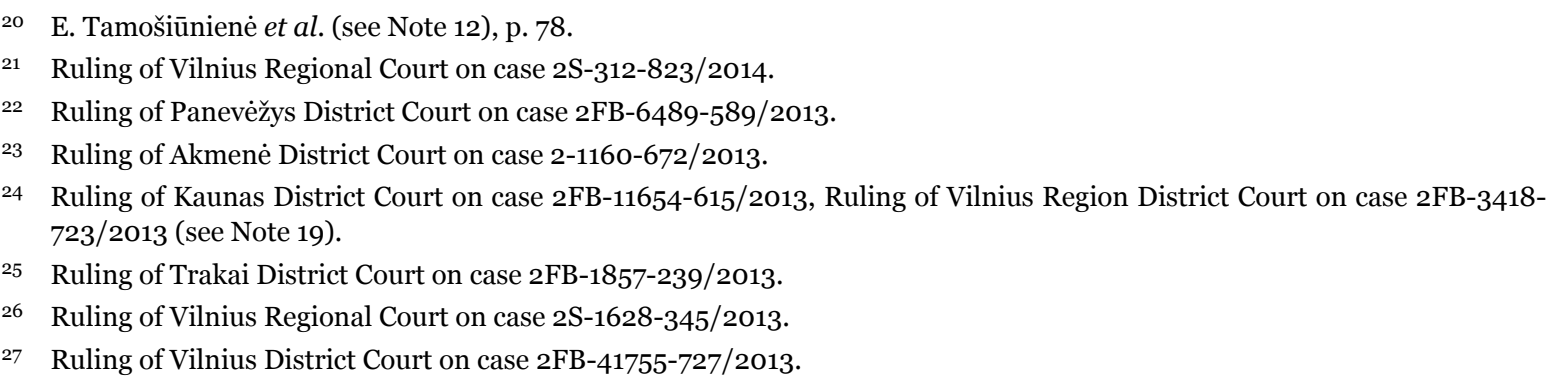


that have been qualified by the courts as dishonest. It is also important to note that the court must in all cases establish the causal link between the circumstances proving a person's unfair actions/omissions and his insolvency ${ }^{* 28}$. Actions of the debtor, even those termed unfair in the LPB, should not preclude the commencement of personal bankruptcy proceedings insofar as they have not caused insolvency of the debtor.

In the opinion of some legal scholars, considering good faith to be a substantive condition for initiation of bankruptcy proceedings, the burden of proof lies with the debtor, who has to substantiate his good faith throughout the proceedings. Supporters of the latter opinion argue that this conclusion follows from the fact that a natural person who seeks bankruptcy and debt relief seeks personal benefit and, therefore, must bear the burden of proof ${ }^{* 29}$. Judicial practice of Lithuanian courts confirms the above-mentioned conclusion by placing the burden of proof with the debtor. ${ }^{*} 30$ The authors of this paper find that position disputable. The general procedural obligation of the claimant to prove his claim is modified by legal presumptions that are established by the legislator in line with the general rules of evidence-in particular, the rule stating that the burden of proof lies with the party who asserts, not with the party who denies (because it might be objectively impossible to prove that something is non-existent). When established by the law, a legal presumption of dishonesty is normally based on certain clearly defined conditions, in the presence of which the obligation, to prove honesty, is transferred to the debtor. The provisions of the LPB do not stipulate a presumption of dishonesty of the debtor, and the above-mentioned explanation of placing the burden of proof on the debtor does not clearly disclose the reason for which the general civil-law presumption of honesty should be disregarded in personal bankruptcy proceedings. It would hardly be fair to assert that the mere fact of insolvency is sufficient for presumption of dishonesty of the debtor. When one takes into account the concept of good faith, as it is understood in the framework of personal bankruptcy proceedings, an obligation of the debtor to prove his honesty means, in fact, an obligation to prove that there were no malicious or grossly negligent actions on his part-i.e., to prove the negative. Therefore, in the opinion of the present authors, honesty of the debtor should be presumed and the burden of proof should rest with the person, a creditor, who states that the debtor was dishonest and that, on that basis, personal bankruptcy proceedings should not be initiated.

According to Article 5 of the LPB, personal bankruptcy proceedings are to be opened and heard in an adversarial procedure as prescribed by the Code of Civil Procedure. That means, inter alia, that the principle of parties' disposition is applicable in personal bankruptcy proceedings. Under the provisions of the Code of Civil Procedure, the right of a court to examine ex officio circumstances of a civil claim is an exception, one linked with the obligation of the court to protect public interests, and is to be exercised for that particular purpose only. In the established judicial practice in relation to bankruptcy of legal persons, the institution of bankruptcy proceedings is deemed to involve public interests, as it causes consequences erga omnes and influences interests of all creditors, who lose the right to satisfy their claims by means of individual execution. ${ }^{*}{ }^{31}$ In this respect, there are no significant differences relative to personal bankruptcy proceedings. Recognition of a public interest in personal bankruptcy proceedings, in turn, leads to the conclusion that the court has a right to assess the debtor's behaviour in light of the principle of good faith $e x$ officio. On the other hand, it is evident that the court will do that only in cases wherein prima facie evidence of dishonest actions by the debtor is present.

Assignment of the burden of proof is related to the problem of sufficiency of evidence for the court's declaration that a debtor was acting in bad faith. In recognition of the presumption of honesty, bad faith of the debtor should be actually proved in this case-the mere implication of dishonesty of a debtor does not constitute a sufficient basis for concluding that, for reasons of violation of the principle of good faith, personal bankruptcy proceedings may not be initiated. This can be illustrated by the example of one of the first cases of personal bankruptcy in Lithuania, filed by a well-known Lithuanian pop singer. The court of first instance in the case mentioned had refused to initiate personal bankruptcy proceedings, basing its judgement mainly on information provided by an Internet portal about the large wedding feast (with 200 guests) planned for the debtor and her subsequent holiday in Argentina. According to the court, 'publicly announced intention of the applicant to organise a wedding celebration for more than 100 people in the

\footnotetext{
28 E. Tamošiūnienè et al. (see Note 12), p. 79.

29 Ibid.

30 For example, the ruling of Panevėžys Regional Court on case 2S-911-212/2013 and of Trakai District Court on case 2FB-1857-239/2013.

31 Ruling of the Court of Appeals of Lithuania in case 2-652/2012.
} 
near future does not show a poor financial situation; on the contrary, it raises reasonable doubts as to whether the applicant was honest when applying to the court" ${ }^{* *}$. This ruling was overturned on appeal, with a statement that a notification about the wedding of the debtor in the mass media is not by itself sufficient evidence supporting the conclusion that her financial situation had improved and that the court should take additional measures in order to ascertain the actual financial situation of the applicant ${ }^{*} 33$.

\section{The payment plan and its implementation}

The LPB draws no clear distinction between individual stages of the insolvency procedure-bankruptcy (sale of the debtor's property) and extinguishing obligations or proceedings for the release of the debtor from obligations-as is done by the relevant legal acts of Latvia and Estonia. Sale of the debtor's property and modification of creditors' claims are to be performed under the same payment plan. Failure to submit a payment plan for court approval within the specified time or court refusal to approve the plan constitutes a basis for discontinuation of personal bankruptcy proceedings.

Article 7 of the LPB lists issues that have to be addressed in a payment plan but leaves for the interested parties the determination of the exact content of the plan. One of the essential questions for creditors and the debtor is what concessions the creditors will have to make and how long it will take before the debtor is released from his obligations. The concessions can take any of various forms: rescheduling of payment of the debtor's obligations, total or partial write-off of creditors' claims, and other modification of payment obligations. The LPB does not expressly provide for immediate discharge for the debtor without any payment to the creditors, nor does it exclude this. Hence, a question could be raised as to whether release from debts in the context of personal bankruptcy proceedings in Lithuania is possible only after their partial repayment or, instead, unconditional release from obligations is possible too under certain circumstances.

When one analyses the existing judicial practice, it seems that the courts are granting priority to the interests of creditors by declaring the ability of the debtor to satisfy the claims of creditors at least partially to be a necessary condition for initiation of bankruptcy proceedings and thereby, in fact, excluding the possibility of writing off the debts of an impoverished debtor. Two examples follow:

The claimant has not proved that, after an improvement of his health (the claimant having a disability rating of 75 per cent), he will be able to gain employment, receive income, and restore his solvency; on the contrary, it appears from the explanations of the claimant and the summary of costs presented that the claimant, receiving only disability pension of 840 LTL and having no property, has calculated that the amount necessary to satisfy his basic needs is 1,400 LTL and provided no additional sources of income [so] the court must take into account the LPB's purpose of restoring the solvency of the debtor by striking a fair balance between the interests of a debtor and those of his creditors. ${ }^{*} 34$

The purpose of personal bankruptcy proceedings under the LPB is not to annul or write off debts of a natural person but to restore the solvency of the debtor in order that he, following the payment plan, could satisfy the claims of the creditors [...]. The court has not established any circumstances proving that the claimant was acting in bad faith [and] one of the essential conditions for going bankrupt under the LPB is to receive income. The claimant receives no income; consequently, she will not be able to repay creditors. The court cannot open bankruptcy proceedings against a person who cannot repay creditors. ${ }^{*} 35$

In the opinion of the authors, the judicial practice referred to above lacks justification and hardly conforms with the intentions of the legislator. As has been mentioned above, the provisions of the LPB do not explicitly exclude immediate discharge of the debtor's obligations without any payment to the creditor. They link the approval of a plan only to the need to strike a fair balance between the interests of a debtor and those of his creditors-in other words, to respect the principle of proportionality. Claims of creditors

\footnotetext{
Ruling of Palanga City District Court in case 2FB-614-83/2013.

Ruling of Klaipėda Regional Court in case 2S-1748-479/2013.

Ruling of Šiauliai District Court on case 2FB-5061-650/2013.

Ruling of Vilnius District Court on case 2FB-38999-833/2013.
} 
constitute a 'possession' within the meaning of Article 1 of Protocol 1 of the European Convention for the Protection of Human Rights and Fundamental Freedoms, and release from obligations is interference with the property rights of the creditors. However, the aims with personal bankruptcy proceedings, such as responding to the need to protect human dignity and avoiding impoverishment, can justify such interference to a certain extent. In the opinion of the ECHR, debt-adjustment legislation clearly serves legitimate social and economic policies and is not ipso facto an infringement of Article 1 of Protocol 1; rather, it must be assessed whether a measure taken in any particular situation respects the fair balance and whether it does not impose a disproportionate burden on the creditor. Although court-ordered irrevocable extinction of a debt, as opposed to the scheduling of payments of a debt over a longer span of time, could in some circumstances result in the placing of an excessive burden on a creditor, the 'market value' of the creditor's claim also should be taken into account. ${ }^{*}{ }^{6}$ If a debtor is unable and will remain unable, at least partially, to repay his creditors for objectively valid reasons (e.g., disablement or reaching of retirement age), it would be unjustifiable to refuse to write off his debts on the basis of protection of rights of creditors, since the possibilities for recovery from such a debtor are in any case practically non-existent. At the same time, inability to repay creditors per se cannot serve as a basis for refusal to initiate personal bankruptcy proceedings. On the other hand, 'fair balance' entails the obligation of the debtor to satisfy creditors' claims to the greatest extent possible in consideration of the circumstances of the individual case. Therefore, unconditional release from obligations is possible only in exceptional circumstances.

In all of the Baltic States, the final word on the approval of a payment plan rests with the court ${ }^{*} 3$. The right of the court to approve a plan even if that plan has been disapproved by the creditors ensures proper balance between the interests of a debtor and those of his creditors, who normally have no interest in debt restructuring. For example, it is noted that procedures for restructuring of legal persons in Lithuania are rarely successful, because it is very hard to gain the creditors' approval to a restructuring plan, which is compulsory in the case of restructuring of legal persons. ${ }^{*}{ }^{38}$ Because judicial practice in approval of a payment plan is still very limited, it is difficult to assess whether creditors will be more benevolent in cases of personal bankruptcy or not. Thus far, in three out of the nine cases in which the payment plan has been approved by the court, the plan was approved by most or all of the creditors (in all cases, these were commercial banks). In the other cases, the payment plan was approved by the court after it came to the conclusion that the creditors had failed to present any valid reasons for disapproval of the plan ${ }^{*} 39$ or that the creditors and the debtor had, in fact, reached agreement on the main conditions of the bankruptcy proceedings-conditions related to satisfying creditors' claims, the duration for implementation of the plan, sale of property, administration costs, and the amounts necessary to satisfy the basic needs of the debtor during the procedure-and opposition to the plan was merely of a formal nature. ${ }^{*} 40$

The period for the implementation of a payment plan in Lithuania cannot exceed five years. The LPB is silent on whether this term could be reduced and under what conditions. A different solution is applied in Latvia, where the time for implementation of the plan for extinguishing obligations of a natural person is determined with consideration for the estimated income during the procedure for extinguishing obligations and can last one year from the day of announcement of the procedure (if the debtor's income is sufficient to cover at least $50 \%$ of the total obligations remaining after the bankruptcy procedure is completed), two years (if the debtor's income is sufficient to cover less than this but at least $35 \%$ of the total obligations), or three years (if the debtor's income is sufficient to cover less than $35 \%$ but at least $20 \%$ of the obligations). If the debtor's income during the procedure for extinguishing obligations is not sufficient to cover at least $20 \%$ of the total obligations remaining after completion of the bankruptcy procedure, the length of the period depends on the debtor's total obligations. If the debtor's income changes during implementation of the plan for extinguishing obligations, he has a duty to prepare amendments to the plan by changing the deadline for the plan and the amount of the obligations to be covered within the scope thereof ${ }^{*} 41$. Such legal regulation

\footnotetext{
36 Judgement of the European Court of Human Rights in the case Bäck v. Finland (see Note 7).

37 Articles 137, 139, 146, 156, and 157 of the Insolvency Law of Latvia; Article 24 of the Debt Restructuring and Debt Protection Act of Estonia; Article 8 of the LPB.

38 Bankrutavo pirmasis fizinis asmuo Vilniaus mieste (see Note 8).

39 Ruling of Kaunas District Court on case 2FB-9404-192/2013.

40 Ruling of Vilnius District Court on case 2FB-19457-79o/2013; Ruling of Kaunas District Court on case 2FB-9404-833/2013; Ruling of Šiauliai District Court on case 2FB-85-291/2013.

41 Article 155 of the Insolvency Law of Latvia.
} 
motivates the debtor to seek a better-paying job or attempt to increase his income in another way, because this affects the time span for the implementation of the payment plan. It is a positive development that the abstracted nature of the LPB with respect to the time for implementation of the payment plan seems to be successfully supplemented by judicial practice. Although the time for implementation of the payment plan approved by the court has been five years in most cases thus far, a tendency to link the span of implementation of the plan with the abilities of the debtor to repay his debts is emerging. For example, it was directly mentioned in one court case that the maximum term for implementation of the plan was chosen in account of the fact that a very limited percentage of debts was expected to be covered after the sale of property. ${ }^{*}{ }^{4}$ In another case, the same conclusion was reached because the debtor had no property and her income was very low. ${ }^{*} 43$ On the other hand, in one of the cases heard, the term of implementation of the plan was only a few months, since the court came to the conclusion that, because the debtors were retired persons, their age and condition of health rendered it impossible to increase their income and repay creditors ${ }^{*} 44$.

\section{Some conclusions}

The model for personal bankruptcy chosen by the Lithuanian legislator is, as are the models of the other two Baltic States, a reflection of the Nordic and German models, which emphasise good faith of the debtor along with the payment plan and its implementation. However, unlike the Estonian model, it does not feature separate procedures for bankruptcy and, on the other hand, debt restructuring, and it places emphasis on the latter. This leads to questionable judicial practice, which declares that the ability of the debtor to satisfy the claims of creditors at least partially is a necessary precondition for initiation of personal bankruptcy proceedings. The statutory requirement of striking a fair balance between the interests of a debtor and those of his creditors does not exclude unconditional discharge of a debtor in exceptional circumstances wherein solvency of the debtor cannot be restored and there are objective grounds for this conclusion. On the other hand, as Lithuanian law does not provide for special debt restructuring procedure for a natural person, bankruptcy is possible also without only partial discharge from obligations; therefore, the courts should not link ability to repay creditors in the future to the formal status of insolvency of a debtor.

Exclusion of imminent insolvency as a basis for personal bankruptcy proceedings can be mentioned as a shortcoming of Lithuanian legal regulation in comparison to the legal regulation found in Latvia and Estonia.

Good faith of the debtor, as a precondition to personal bankruptcy proceedings, should be presumed, and the burden of proof should rest with the creditor who claims that the debtor was dishonest. In the case of prima facie evidence of dishonest actions on the part of the debtor, the court should ex officio request the debtor to present evidence of his honesty. Any bad faith of the debtor should be properly established, whilst a mere suggestion of dishonesty of a debtor is not a sufficient basis for concluding that personal bankruptcy proceedings may not be opened.

When deciding on the approval of a payment plan, the court, taking into account the circumstances of the individual case, should observe the principle of proportionality by ensuring that an excessive burden is not placed either on the debtor or on creditors. The amount of time for implementation of the payment plan should be linked with the value of the debtor's property and his estimated income.

\footnotetext{
Ruling of Klaipèda District Court on case 2FB-1357-838/2013.

Ruling of Klaipedda District Court on case 2FB-1247-838/2013.

4 Ruling of Kaunas District Court on case 2FB-9404-192/2013.
} 